УДК 821.161 .1

Михайло ЖИЛІн

к. філол. наук, Донецький національний університет імені Василя Стуса

\title{
«РОЗДУМИ ПРО БОЖЕСТВЕННУ ЛІТУРГІЮ» МИКОЛИ ГОГОЛЯ: МІЖ ПОЕТИКОЮ ТА ЕКЗЕГЕТИКОЮ
}

Статтю присвячено порівнянню двох традицій вивчення творчості Гоголя - формалістичної та православно-екзегетичної. Перша традиція в загальнотеоретичному плані була продовжена формалістичним напрямком у літературознавстві. Водночас сучасна російська наука про Гоголя розглядає його пізню творчість, виходячи винятково з уявлення про іiі релігійний характер, ігноруючи художність. Як наслідок, методологія стає жертвою нового, на цей раз релігійного, детермінізму, подібного за своєю природою до старої радянської методологічної традиції - вульгарного соціологізму.

Ключові слова: Микола Гоголь, «Роздуми про Божественну Літургію», поетика, детермінізм, формалізм, Православ'я.

«Роздуми про Божественну Літургію» Миколи Гоголя, що побачили світ уже по смерті автора (уперше завдяки П. Кулішеві) й мали дуже непросту цензурну історію, є твором, недостатньо дослідженим з богословської позиції й геть проігнорованим філологами. Винятками, які лише підтверджують загальний невтішний стан речей, є грунтовні праці двох російських православних філологів - Ігоря Віноградова [1; 2], та Владіміра Воропаєва [3], присвячені історії створення та публікацій (стаття Воропаєва), а також місцю «Літургії» у творчому спадку і - головне - «духовному життєписі» Гоголя. Під останнім розуміємо стійке намагання авторів подати внутрішню i творчу біографію Гоголя як безупинний шлях до ідеалу православної релігійності та російського (= православного) патріотизму. Згідно із загальною інтенцією цих праць до iдеалу Гоголь почав наближатися ще до народження («цьому чимало сприяли бабуся Гоголя Тетяна Семенівна та його мати Марія Іванівна» [2, 465]), а досягнуто iдеалу було вже в «Літургії»: «Таким чином, за доби розпаду, який щойно розпочався - у цей час, коли вже складалася психологія нової «російської інтелігенції», для якої приносити користь Росії, працюючи в 
державному закладі, здавалося ганьбою, Гоголь закликав до державного служіння як релігійного обов’язку: Монастир ваш - Росія!» $[1,387]$. ...А може навіть далеко по смерті, адже «про те, що Гоголь успішно впорався зі своїм завданням ознайомлення молодих людей зі смислом православного богослужіння й черговістю його дій, говорить той факт, що Імператриця мучениця Александра Феодорівна $з$ метою пояснення Цесаревичеві Алексію обідні читала разом 3 ним «Роздуми про Божественну Літургію» Гоголя» [3, 26].

В. Воропаєв та I. Віноградов малюють широку панораму того християнського світу, в якому формувався Гоголь, як людина глибоко релігійна, і в якому визрівав задум його підсумкового твору. Перераховуються всі віруючі рідні та близькі Гоголя, каталогізується величезний масив релігійної лектури: як тієї, що Гоголь читав чи хотів прочитати, так і тієї, яка просто була поширена в Російській Імперії початку XIX століття. Ці та інші, часто дуже опосередковано пов'язані із самим Гоголем історичні факти, на думку вчених, свідчать про питому й захищену від «тлетворності модних вчень» його православність, а відтак, і певну передвизначеність появи його «Літургії». Інколи мета настільки виправдовує засоби, що деякі факти тлумачаться навіть (тут дуже доречною $є$ ця улюблена гоголівська частка) гротескно. Ось, наприклад, такий пасаж: «У цілому можна сказати, що освіта в Ніжинській гімназії багато в чому нагадувала семінарську. Сам Гоголь у вірші, написаному 1836 року разом зі шкільним товаришем О.С. Данилевським, жартома називав Ніжинську гімназію бурсою («Да здравствует нежинская бурса...»). Н.В. Кукольник, своєю чергою, іронічно називав гімназію «монастирем мудрості» й повідомляв, що збирається «ув’язнитися» («заключиться») у ньому, «возложив на себя знаки монашеского смирения» [2, 476]. Попри те, що гімназія в наведеному вірші названа «бурсою», що є властивим романтикам іронічним обниженням предмета («мы все учились понемногу чему-нибудь и как-нибудь»), i І. Віноградов не міг цього не відчувати; пори те, що 
ISSN 2308-1902 Актуальні проблеми української літератури і фольклору. 2017. № 25.

характеристику, надану Кукольником, сам учений називає іронічною, - попри це, «ніжинська бурса» використовується як ще одне підтвердження кришталево-християнскої освіти Миколи Васильовича.

Загалом у цитованій праці І. Віноградова обгрунтуванню положення про глибоку православну освіту, яку здобув Гоголь у гімназії, присвячено аж 10 сторінок тексту - набагато більше, аніж з’ясуванню інших впливів на формування в нього релігійного духу. Але дивно, як учений прогавив той факт, що сам Гоголь у згаданому вірші просто в кількох рядках заперечує цю роль гімназії у формуванні життєвого шляху іï випускників. Ось цей юнацький жартівливий віршик, «куплет» за визначенням О. Данилевського:

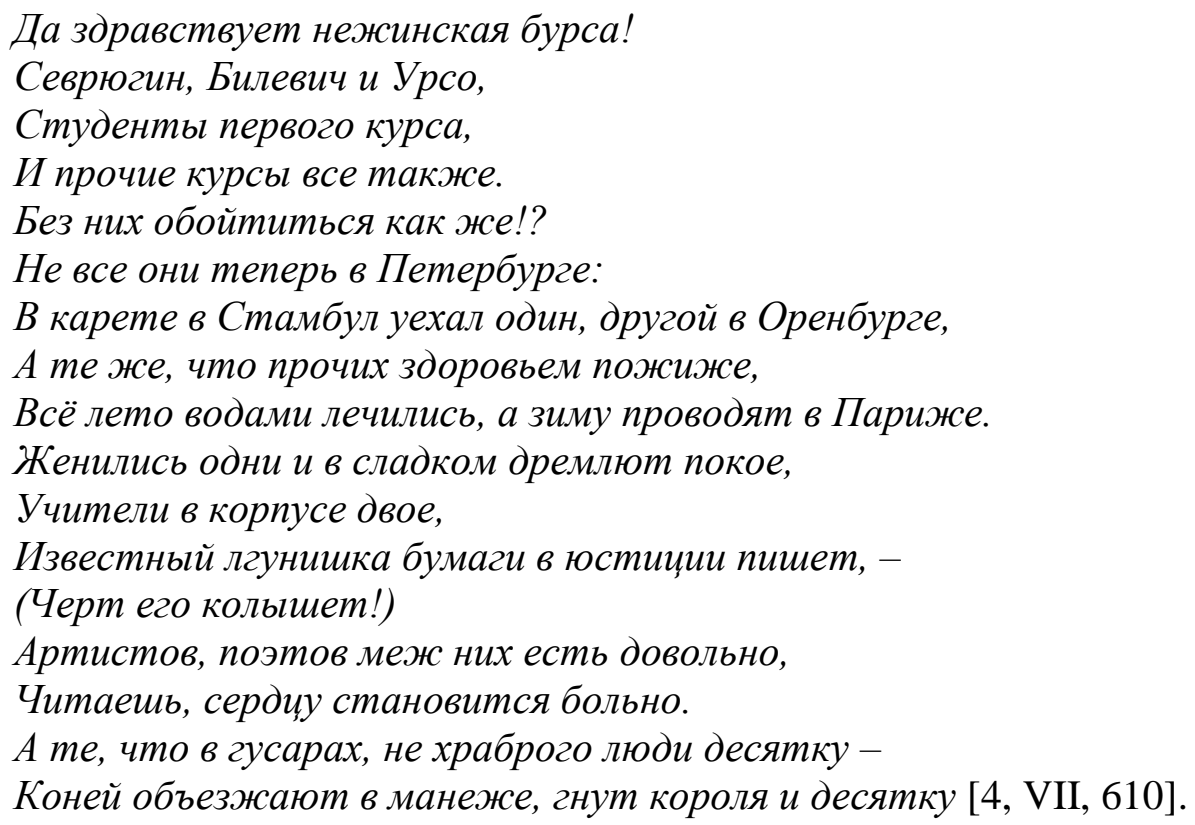

Здається, Гоголь жодного слова не говорить про бодай якийсь релігійновиховний вплив гімназії на студентів, навіть навпаки.

Про драматичний, тривалістю в ціле життя діалог Гоголя 3 релігією написано стоси праць. Про «апостольство» Гоголя у прямому, неметафоричному значенні цього слова писав, наприклад, Павло Михед [5, 5]. Але тільки у Віноградова та Воропаєва (з відомих учених) знаходимо оцю агіографічну схему Гоголевої святості, яку можна розцінити як спробу формування уявлення про письменника - святого подвижника. Принаймні весь пафос цих «житій» Гоголя наводить на таку думку. I це виходить 3-під пера не 
протоієрея Георгія Флоровського чи імперців К. Мочульського або І. Ільїна, а стараннями сучасних філологів. Зрештою, не можемо не пристати до твердження Юрія Барабаша про те, що «у російському гоголезнавстві активізується тенденція до інтерпретації гоголівської спадщини 3 неослов'янофільських, войовничо імперських позицій. Представники цієї течії [...] розглядають спадщину М. Гоголя у контексті т. зв. православного коду російської літератури, прив'язують письменника до політичних і духовних цінностей російського самодержавства, ортодоксальної, одержавленої московської Церкви» $[6,254]$. Це таке своєрідне, питомо російське, дивне як на філологію XXI століття політико-релігійне гоголезнавство, в якому творчість Гоголя (особливо «Вибрані місця...» та «Роздуми про Літургію») - не об'єкт наукового дослідження, а символ общерусскости. Кульгаво, але вкрай симптоматично звучать слова філолога, ієромонаха Симеона (Томачинського): «На жаль, зараз на батьківщині Гоголя його видають українською мовою, де все нещадно переробляється. Де письменник каже «русская земля», вони пишуть «українська земля», де класик говорить про силу російського народу [«русского народа» - в оригіналі], вони пишуть «українського народу» i таке інше. Жорстокій цензурі піддають його твори, силоміць роблячи Гоголя якимось навіженим націоналістом. Це не викликає поваги, це наруга над пам'яттю письменника [...]. А Росія, за Гоголем, після падіння Константинополя, після арабо-мусульманських завоювань - це остання й головна твердиня православ'я, і лише в союзі з нею Україна може захистити православну віру» [7].

У принципі, православна апологетика Гоголя може мати місце i в літературознавстві, а захист його общерусскости - це природне право росіян. Та природніше було б бачити їх на периферії власне філологічного дискурсу, як проблеми здебільшого з царини філософської чи богословської публіцистики. Наразі спостерігаємо ситуацію, коли інтерпретація пізньої творчості Гоголя стала заручницею силоміць накиненого ззовні методологічного (чи навіть ідеологічного) монізму. Ми вже побачили небезпеку цього монізму в плані 
ISSN 2308-1902 Актуальні проблеми української літератури і фольклору. 2017. № 25.

викривленого (ідеологія як «перевернуте відображення дійсності» в молодогегельянців) сприйняття деяких фактів біографії та творчості Гоголя (казус із бурсою). Але ще більша небезпека такого монізму, підтримуваного (що дуже важливо) ззовні, московською церквою, у тому, що він анексує територію всієї пізньої творчості Гоголя, фактично відмовляючи ій у літературності й наголошуючи на іï душеспасительній релігійності. Винятки, авжеж, існують. Але численні репліки щодо суб'єктивності, чуттєвості, естетичності «Роздумів про Літургію» слугують винятково для виправдання недостатньої обізнаності письменника «у тонкощах догматичного богослов'я», адже «твір Гоголя не переслідував наукових завдань і в цьому аспекті поступається багатьом дослідженням і навіть посібникам з курсу богослужіння чи літургіки. «Роздуми про Божественну Літургію» - це продукт не стільки розуму, скільки сердечної віри» [3, 24]. (Це виправдання хиби «простого вірянина», який у «Літургії вірних» дійшов ледь чи не до сповідування «єретичного» filioque i був посмертно відцензурований архимандритом Кіріллом). Зрештою, художність «Літургії» констатується і в зовсім утилітарному аспекті - як дієвий засіб до навернення вірян до активного церковного життя: «Маємо свідчення від найрізноманітніших людей, що одним з перших етапів шляху до Бога та Церкви стало для них прочитання «Роздумів про Божественну Літургію» Гоголя» $[8$, 84].

Принципове редукування естетичного в інтерпретації пізньої творчості Миколи Гоголя не дозволяє застосувати до ії аналізу власне філологічні методи дослідження, відсуває на маргінес гоголезнавства ті глибокі й тонкі спостереження над словом і образом у творах письменника, які виробила філологічна наука впродовж останніх півтораста років. Перед нами, по суті, вже два Гоголі: це далебі не Маланюкові «Гоголь - Гоголь», а оптинсько-московські «Письменник - Проповідник». Екзегетика стає повноправним господарем на тій території, яку раніше контролювала і мусить контролювати поетика. 
Продемонструємо це на конкретному прикладі. 1921 року Роман Якобсон пише свою класичну працю «О художественном реализме». У ній учений намагається позбавити термін «реалізм» властивого йому й зумовленого функціонуванням історії літератури в ранзі causerie «некритичного вживання». Проблема, пише Якобсон, у тому, що реалізм традиційно сприймається як іманентна властивість художнього твору $(A)$ або як наше сприйняття цього твору як «достовірного» $(B)$. Ці дві модальності зазвичай не розрізняються й зрештою екстраполюються на цілу епоху в літературному процесі, створюючи еклектичну концепцію «певного художнього напрямку XIX століття» $(C)[9$, 388]. Якобсон найперше піддає обструкції уявлення про «достовірність», «правдоподібність» як притаманні будь-якому мистецтву: насправді, немає критеріїв, за якими ту чи іншу метафору або метонімію можна вважати більш чи менш правдоподібними. Причина цього - обов'язкова і природня для твору мистецтва «умовність». Умовність деформує уявну правдивість дійсності. Відтак, de lege ferenda митець удається до «мотивування деформації ідеограм» [Там само]. «Деформація» виникає вже в момент добору слів. Важко сказати, наскільки постійний, заяложений, приміром, епітет може бути «правдоподібнішим», ніж різка, оригінальна метафора чи фігуральний зворот. «Така характеристика за допомогою неістотних ознак уявляється адептам нової течії більш реальною, аніж скам'яніла традиція, що їм передувала» [9, 389]. Якщо ми констатуємо можливість деформації ідеограм, то, відповідно, і наші уявлення про реалізм деталізуються на $A_{1}, A_{2}$ - усвідомлене бажання/небажання автора вдаватися до деформацій та $B_{1}, B_{2}$ - позитивна/негативна оцінка реципієнтом таких деформацій. Історія мистецтва демонструє безліч випадків заміщення цих уявлень.

Звернімося до Гоголя, а саме, до афектації майора Ковальова 3 повісті «Ніс»: «Конечно, я... впрочем, я майор. Мне ходить без носа, согласитесь, это неприлично. Какой-нибудь торговке, которая продает на Воскресенском мосту очищенные апельсины, можно сидеть без носа; но, имея в виду получить... 
ISSN 2308-1902 Актуальні проблеми української літератури і фольклору. 2017. № 25.

притом будучи во многих домах знаком с дамами: Чехтарева, статская советница, и другие... Вы посудите сами... я не знаю, милостивый государь. (При этом майор Ковалев пожал плечами.) Извините... если на это смотреть сообразно с правилами долга и чести... вы сами можете понять...» [4, III, 46]. Що ми дізнаємося 3 цієї репліки у плані «відображеної в ній дійсності»? Практично нічого, крім того, чого не можна було б передати дуже коротко й змістовно висловом: «Я - поважна людина, майор. А поважна людина не може ходити без носа». Які «правила обов'язку і честі», яка це Чехтарьова і - головне - чому надається перевага «какой-нибудь торговке, которая продает на Воскресенском мосту очищенные апельсины» над, скажімо, візником, що транспортує в тарантасі титулярних радників Анічковим мостом? Цей художній світ «фантастической чепухи» вже давно став предметом серйозних філологічних студій. Незадовго до статті Якобсона побачила світ відома розвідка В. Віноградова, присвячена цій незвичній гоголівській стилістиці. У ній дослідник доходить, зокрема, такого висновку: «Утвердження на цій основі нових форм стилістичної побудови, відвернутих і вивільнених від номінативнопобутових зв'язків слів, було в той самий час процесом творення «нової художньої дійсності», яка, хоч вона й була пов'язана 3 літературними традиціями, водночас співвідносилася безпосередньо з дійсністю побуту - на принципах «невідповідності» $[10,44]$.

У праці «Гоголь і натуральна школа» В. Віноградов спробує конкретизувати поняття «нової художньої дійсності» не через «горизонт очікувань», а через іманентну здатність стилю до саморозвитку: «I всі герої, уся «натура» оповіді постає, як об'єктивно дана, а не викривлена свідомістю оповідача. Створюється ілюзія справжніх «кривих пик», адже «криве дзеркало», що відображає, є завуальованим, прихованим. Це - «натуралізм». Однак, Гоголь, не ховається цілком. Навпаки, він накладає на себе машкару «сентиментальної», палкої натури й починає перебивати об'єктивно-стилістичні відтворення ліричними звіряннями. [...] Цей другий стилістичний струмінь 
мусив стрімко вриватися в основний натуральний шар: переходів між ними не могло бути, позаяк прийоми натуралістичного рисування подано в I томі «Мертвих душ» в оголеному вигляді, без жодного пристосування до елементів сентименталізму. Це - було механічне злютування контрастних художніх форм. Почалося спливання Гоголя до сентименталізму. Проблема синтезу 3 ним натуральної манери стає болючою художньою загадкою, над якою Гоголь побивався до смерті. Пройшовши крізь горнило натуралізму, що виник, як реакція на сентиментальні форми, Гоголь не зміг знову стати сентименталістом, хоча його тягнули в цей бік і ворожа критика, i сучасні літературні течї̈, i навіть особисті релігійно-моральні переконання. Але він став здавати сентименталізму одну за одною свої колишні літературні позиції» [11, 62].

У цих висновках В. Віноградова все є дуже важливим, попри те, що немає підстав 3 такою стовідсотковою впевненістю говорити про «навернення» пізнього Гоголя саме до сентименталізму (навіть беручи це слово в лапки). Втім це окрема часткова проблема, до якої будемо повертатися. Для нас важливий методологічний прецедент, що дозволяє конкретизувати й універсалізувати твердження Якобсона про характер відношення мистецтва до його денотата, опосередковане словом і прийомом, щодо творчості Гоголя. «Необов'язкова» деформація - «торговка, которая продает на Воскресенском мосту очищенные апельсины», - якщо застосовувати схему Якобсона, з точки зору старих сентименталістів, належатиме до групи явищ, яку останній умовно позначає як $B_{2}$; 3 точки зору Гоголя як автора - це $A_{1} ; 3$ точки зору представників «натуральної школи», які вважали Гоголя своїм вождем, - це $B_{1}$, 3 точки зору «ворожої критики» i, припустимо, «особистих релігійноморальних» переконань пізнього Гоголя - це $\mathrm{B}_{2}$. Щоб підкреслити похідний характер несприйняття такої деформації (не в момент творення, а у випадку вторинної інтерпретації, «переінтерпретації») дозволимо собі ускладнити формули Якобсона: для критики це буде $A_{1} B_{2}$; для пізнього Гоголя («знаю, что моими необдуманными и незрельми сочинениями нанес я огорченье многим, а 
ISSN 2308-1902 Актуальні проблеми української літератури і фольклору. 2017. № 25.

других даже вооружил против себя, вообщуе во многих произвел неудовольствие» $[4, \mathrm{VI}, 8])$ - це $A_{1} A_{2}$.

Свою теорію Якобсон розробляє (у цьому випадку) для того, щоб показати (див. вище), що $C$ - усього-на-всього продукт наукового інфантилізму (додамо можливість зумисного опрощення): «Позаяк усталилася традиція, що реалізм - це $C$, нові художники-реалісти (у сенсі $A_{1}$ цього терміна) змушені оголосити себе неореалістами, реалістами у найвищому сенсі цього слова або ж натуралістами, встановлювати відмінність між реалізмом приблизним, гаданим (C) та, на їхній погляд, справжнім (тобто своїм)» [9, 391]. Цьому «приблизному» реалізму Якобсон протиставляє більш конкретний «прогресивний» реалізм, що його він і ототожнює зрештою 3 так званою «гоголівською» школою. Стилістичною ознакою (або ж у формалістській термінології - прийомом) цього реалізму $є$ «ущільнення оповіді образами, залученими за суміжністю, тобто илях від власного терміна до метонімї та синекдохи» [Там само]. Цей новий тип реалізму, елементи якого часто зустрічаються в $C$ («сумочка Анни Карєніної»), автор статті позначає як $D$.

По-перше, схеми В. Віноградова та Р. Якобсона, є частиною давньої традиції спостережень над гоголівським словом. Ці спостереження своїм корінням сягають, як це не парадоксально, негативної, заангажованої й часто в’їдливої критики Степана Шевирьова та Осипа-Юліана Сєнковського (Барона Брамбеуса). Перший опублікував на шпальтах погодінського «ученолитературного журнала» «Москвитянин» за 1841 рік дві статті під загальною назвою «"Похождения Чичикова, или мертвые души", поэма Н. В. Гоголя», в якій читаємо, зокрема, таке: «Комічний гумор автора іноді заважає йому охоплювати життя в усій його повноті й широкому обсязі. Це стає особливо ясним у тих яскравих спостереженнях про російський побут i російську людину, якими пересипано поему. Здебільшого ми бачимо в них один негативний, смішний бік, півперехвату, а не весь перехват російського світу. Усяка глупота й безглуздя [«глупость и бессмыслица» - в оригіналі] яскраво 
лягають під влучний пензель поета-гумориста» [підкреслення наші. - М.Ж.] [12]. О. Сєнковський у своєму їдкому фейлетоні-притчі вченого сноба, що вийшов у «Библиотеке для чтения» менш ніж за рік, конструює розмову трьох тварин - бика, віслюка та верблюда - про «возвышенность $u$ глубокомысленность приключений Чичикова». У цій трохи забутій алегорії чимало влучних спостережень, серед яких і чудернацька мова Гоголя, дивовижна граматика його словесних конструкцій, і цілковита відсутність того, що «академісти» вважали смаком, і навіть неспроможність Гоголя створити щось по-справжньому смішне: « Вот, уж ты и сердишься, Горбунов! прервал его осел. Tы ученое животное, а совсем не понимаешь тонкости вещей: грязные и зловонные картиныц!.. что̀ же тут дурного?.. они необходимьл в нашей поэме, для возбуждения «высокого восторженного смеху», который достоин стоять рядом с «высоким лирическим движением» [...]. Силич хочет облагородить грязь и вонь, возвести их в «перл создания», как мь говорим в намей пиитике, сделать их предметами умственного наслаждения. Предприятие смелое, великое, высокомерное, но оно достойно его гения» [13, 236]. Цей несвідомий діагноз революції в літературному процесі, даний Сєнковським гоголівському стилю, завершується профетичним пуантом: «Грязь на грязи! с отвращеенем подумал чистоплотный верблюд.

- Красота на красоте! с восторгом подумал осел. Какое остроумие! Сколько поэзии!» $[13,240-241]$.

I Шевирьов, і Сєнковський мимохіть готують той зворот до поетики Гоголя - поетики як вивчення процесу перетворення людського мовлення на художній твір, - який дуже чітко означить Б. Ейхенбаум: «Композиція у Гоголя не визначається сюжетом - сюжет у нього завжди бідний, радше - немає жодного сюжету, а взято лише якийсь один комічний (а іноді навіть власне зовсім не комічний) стан, що слугує нібито лише поштовхом чи приводом для розробки комічних прийомів» [14, 307]. Ці прийоми формують, за Ейхенбаумом, специфічна гоголівська оповідь (в оригіналі - «сказ»), що, відтак, 
ISSN 2308-1902 Актуальні проблеми української літератури і фольклору. 2017. № 25.

є смисло- та структурнотвірним елементом творчості письменника: «Текст його складається $з$ живих мовленнєвих уявлень та мовленнєвих емоцій. Більше того: ця оповідь має тенденцію не просто оповідати, не просто говорити, а мімічно та артикуляційно відтворювати слова, і речення обираються й зчіплюються не за принципом лише логічного мовлення, а передовсім за принципом мовлення виразного, у якому особлива роль належить артикуляції, міміці, звуковим жестам тощо. Звідси - явище звукової семантики в його мові: звукова оболонка слова, його акустична характеристика стає в мовленні Гоголя значущою незалежно від логічного чи речового значення» [14, 309].

Ця надзвичайно продуктивна в методологічному плані лінія гоголезнавства стала однією 3 підвалин загалом формального методу в літературознавстві - поетика Гоголя i «гоголівської школи» через посередництво Романа Якобсона захопила й українську гуманітаристику. Так, після інтенсивного листування Р. Якобсона 3 П. Тичиною у другому числі журналу «ВАПЛІТЕ» за 1927 рік з'являється й український переклад 3 красномовним критичним коментарем редакції: «Друкуючи статтю Романа Якобсона, редакція погоджується з першою їі частиною, з не новим, правда, але уточненим історико-літературних термінів. Що-ж до другої частини, редакція вважає, що, взявши приклади виключно з сфери слова-образа (а не, скажімо, 3 сфери художньої прози, що користується дуже широко також і словом терміном), автор подався вбік чистого потебнянства, 3 яким редакція солідаризується тільки в сфері поетичного слова (не в сфері всієї белетрестичної фактури) [15, 163].

Можна заперечити, що розуміння поетики як феномену, зосередженого на мовленнєвих трансформаціях, є завузьким, однобоким. Таке заперечення може бути подвійним. На першому аспекті його зупинимося в цій статті.

Увага до дрібниць, до отих «прийомів оповіді», мало залежних від загальної «фабули», до «каламбурів різних видів», до «речових метафор, масок», у яких Гоголь вловлює «комізм речі» $[16,201]$ etc., про які йдеться в 
маніфестах ОПОЯЗу, можуть вважатися поетикою «нижчого рівня», протилежною якійсь жаданій у контексті православної філології істинної поетики. Що це за істинна поетика і чим вона відрізняється від предмета досліджень формалістів, можемо дізнатися 3 такої найновішої тези I. Віноградова: святоотецька традиція витлумачення біблійних притч передбачає зосередженість зусиль дослідника лише на головному смислі, він має нехтувати другорядними особливостями тексту, а «ігнорування цього важливого теоретичного принципу, «захоплення» дрібницями на шкоду головному невідворотно призводить до спотворення смислу притчі» $[17,416]$. Освячуючи цей ключовий методологічний принцип посиланнями на Івана Золотоустого, Теофілакта Болгарського та біблеїста початку минулого століття Бориса Гладкова, І. Віноградов провадить про його «універсальність» та конечність його застосування під час тлумачення всіх (!) виявів словесного мистецтва, церковних і світських. «Але необхідність такого підходу, продовжує вчений, - набагато зростає під час вивчення проблемних текстів, що викликають принципову полеміку критиків та дослідників» [17, 417].

У цій методологічній преамбулі все прекрасно: і примусове перенесення методів біблійної герменевтики на художню літературу, і впевненість ученого у своїй здатності відділити кукіль від пшениці в літературному тексті, і очевидна полемічна спрямованість «такого підходу» проти всіляких ейхенбаумівтинянових 3 їхнім нескінченним копирсанням у «прийомах», «масках», «інтонаціях», калейдоскопічності жанрових і стильових взаємодій, i навіть оприлюднення такого важливого методологічного відкриття в ніби цілком серйозному науковому журналі IMЛI PAH. I найголовніше - позаяк застосування будь-якого методу $є$ успішним у разі отримання позитивного результату дослідження, то треба поглянути й на результат, отриманий I. Віноградовим. Таким позитивним результатом, так би мовити діамантом, що лишається після «обдирки» шматка земної кори, у випадку з аналізованими у статті «Вибраними місцями» $є$ унікальний висновок І. Віноградова про 
nатріотизм як смислове осердя твору. Решта - «малоістотні деталі», симулякр, яким Бєлінський підступно приховав істинний смисл «Листування»: «На жаль, ані сучасні, ані наступні критики, читачі та дослідники «Вибраних місць 3 переписки 3 друзями» не помітили підміни сутності полеміки, відтак, за дрібницями, за накинутими Бєлінським суперечками щодо окремих питань, прогледіли головне, неминуще значення гоголівської книги - їі якнайглибший релігійно-патріотичний пафос» $[17,424]$. Хочеться продовжити тему й припустити, що якби Гоголь жив у наш час, то він коли б і не воював за «русскій міръ» на Донбасі, то точно служив би якимось «помощником столоначальника первого стола по второму отделению» Міністерства культури РФ, адже, наприклад, «у той самий час, коли двадцятирічний «червоний республіканець і соціаліст Н.Г. Чернишевський мріяв про «поразку росіян» в Угорщині, Гоголь зі сторінок своєї книги звертається до сучасників, не зраджуючи при цьому жодному зі своїх колишніх поглядів» $[17,420]$.

Усе це настільки комічно, що можна було б і не звертати уваги, якби не важлива методологічна проблема, артикульована у статті. Річ у тому, що I. Віноградов абсолютно підставово кваліфікує (хоча в жодному місці не коментуючи таку кваліфікацію) пізню прозу Гоголя як словесність, а не художню літературу у звичному для нас значенні. Щоб простежити логіку І. Віноградова (а відтак, і всієї «православної школи» в гоголезнавстві) варто згадати міркування С. Аверінцева, безсумнівно відомі дослідникові, про т. зв. «передлітературу», поняття тотожне словесності: «Вихідний пункт будь-якого історико-літературного розвитку - синкретична єдність словесного мистецтва та позалітературних ситуацій, що обслуговуються ним, насамперед побутових і культових [...]. У певній ситуації доречно поводитися так, в іншій - інакше; і гатунки словесного мистецтва, фольклорної і писемної «передлітератури» визначаються саме через цю позалітературну доречність» $[18,105]$. Слово «словесність» у назві статті І. Віноградова, як бачимо, не просто патетичний архаїзм, а цілком адекватний загальній інтенції пізньої гоголівської творчості 
термін: «Целью этой книги, - починає свої «Роздуми про Божественну Літургію» Гоголь, - показать, в какой полноте и внутренней глубокой связи совершается наша Литургия, юношам и людям, ещуе начинающим, ещуе мало ознакомленным с ее значением» [4, VII, 349], - i сам автор фіксує цю «позалітературну доречність». Але і Аверінцев, і сама історія вчать нас, що література не є назавжди приреченою бути служницею позалітературного жесту: «Разом з ускладненням і витонченням словесної культури виникали й такі гатунки, у яких ритуально-побутовий характер не мав щільності й речовинності» $[18,106]$. I це Аверінцев пише про епос від «Гільгамеша» до «Іліади» та «Одіссеї», дидактичні афоризми від «Висловів Птаххотепа» до «Книги Притч Соломонових» і сентенцій Сімох Мудреців Еллади. Навряд чи в кого вистачить сміливості аналізувати стиль автора середини XIX століття 3 погляду законів, що діяли не просто на світанку емансипації художньої літератури від ритуалу та побуту, а ще до Птаххотепа. Але І. Віноградову такої сміливості не бракує - i він поширює настанови Отців Церкви та їхніх послідовників не лише на Гоголя, а й на літературознавство в цілому!

Отже, ми з’ясували, що в цілому правильне (mutatis mutandis, авжеж) adjecto, тобто називання пізньої творчості Гоголя словесністю, призводить до contradictionis у словах про релігійно-патріотичний пафос як справжній смисл його творчості. Саме так - усієї його творчості, адже «Листування» готувалося вже «Тарасом Бульбою». Чому ж дослідник припускається у своїх умовисновках цього contradictionis in adjecto? Тому, що зумисно випускає той історичний інтервал, який відділяє добу авторської суб'єктності (іноді навіть гіпертрофованої) від доби писань Отців і апологетів Церкви. Методологічний імператив I. Віноградова можемо назвати крайнім виявом притаманного сучасній російській науці православного детермінізму - явища, що заслуговує на окреме розлоге дослідження.

Ми торкнемося лише одного аспекту цього досі, на жаль не вивченого українського наукою феномену - його тоталітарності. Міркування Івана 
ISSN 2308-1902 Актуальні проблеми української літератури і фольклору. 2017. № 25.

Золотоустого про тлумачення притч стають обов'язковою передумовою для будь-якого літературознавчого дослідження. При цьому слід відкинути історичний контекст таких міркувань, універсалізуючи їх, визнаючи їх infallibilitum бодай щодо мистецтва. Жертвою тоталітарності православ'я в літературознавстві стає навіть біографія особистості. Погляньмо на таке твердження В. Воропаєва, обмежившись одним-єдиним коментарем: «Відомий богослов та історик Церкви А.В. Карташов у нещодавно перевиданій у нас книзі «Вселенські собори» пише, що Гоголь «покаянно відкинув усе плотське й заморив себе голодом у подвигу спіритуалізму». Літературознавець М.Я. Вайскопф у книзі «Сюжет Гоголя» стверджує, що смерть письменника «була типовим замаскованим самогубством гностика, що розриває плотські узи. Однак правильно зрозумілий піст аж ніяк не може слугувати причиною смерті людини. А те, що Гоголь розумів піст у церковному дусі, неспростовно свідчать його виписки 3 творінь святих отців» $[18,125]$. Коментар такий - яким чином «виписки з творінь святих отців» можуть щось прояснити в такій глибоко інтимній ділянці, як смерть? І головне - для чого ця прив'язка?

Річ у тому, що тоталітарність православного детермінізму - це звичайна тоталітарність будь-якого детермінізму. У випадку з опусами I. Віноградова та Воропаєва останній (детермінізм) не лише передбачає й освячує симулятивні висновки про «релігійно-патріотичний пафос» як основний смисл цілої Гоголевої творчості чи про безгріховність його смерті, але й готує грунт для геть чудернацьких міркувань. Так, на характеристичне запитання: «Як сполучається православ'я Гоголя з усією тією бісівщиною, що про неї він писав, у тому числі й у молодості?» - ієромонах Сретенського монастиря і за сумісництвом філолог Симеон (Томачинський) відповідає: «Гоголь переживав чимало за що написане, хоча в ранніх його творах не було якогось богоборства чи язичництва. Можливо, сприйняття Гоголем християнських ідей в юності було поверховішим, як це часто буває. Тому дії диявольських сил були для нього радше предметом сміху, і він уважав, що можна жартувати з такими 
речами, з якими насправді жартувати не варт. Саме за це він потім каявся» [7]. Тобто насправді маємо справу з абсолютно спекулятивним підходом, механізм дії якого цілком тотожний тому, що прийнято називати вульгарним соціологізмом. Не випадково навіть оцінки та засновки (а детермінізм передбачає передовсім засновок та оцінку, а не аналіз) творчості Гоголя в «соціологів» і «богословів» від літературознавства часто збігаються: «3 величезною художньою силою Гоголь показав не лише процес розкладу феодально-кріпацької системи й духовного зубожіння ії представників, але й ту страшну загрозу, що ніс народові світ Чичикових - світ капіталістичного хижацтва. У своїй творчості письменник відобразив тривогу поступових сил російського суспільства за історичну долю своєї країни та свого народу. Великим патріотичним натхненням просякнуті твори Гоголя» $[19,6]$. Маємо тут i «духовність», i «патріотизм», i, авжеж, лише «головний смисл творчості» без малоістотних деталей. Засновки й оцінки. У Машинського зацікавлення Гоголя в мистецтві під час навчання у гімназії детермінується «гнітючою атмосферою казенної схоластики, що панувала на заняттях у деяких викладачів, змушувала вихованців гімназії шукати задоволення своїх духовних інтересів поза шкільними авдиторіями» [20, 14]. У І. Віноградова - навпаки: головний твір Гоголя «Літургія» є продуктом тієї таки гімназіальної «схоластики» (тільки компліментарно оціненоі): «Слід сказати, що уважне ставлення до того, що відбувалося під час Літургії було властивим Гоголеві не лише в зрілому віці, але ще за ранніх, юнацьких років - від часу його навчання в Ніжинській гімназії вищих наук у 1821 - 1828 роках. Тут слід мати на увазі, що саме в часі початку навчання Гоголя в школі релігійній освіті у світських навчальних закладах Росії стала приділятися підвищена увага» $[1,375]$. Якщо в Машинського потреба Гоголя в «запереченні потворної дійсності» [20, 5] детермінується, зокрема, «подіями 14 грудня в Петербурзі та повстанням Чернігівського полку, що майже одночасно спалахнуло в Україні (29 грудня 1825 р. - 3 січня 1826 р.), які не проминули повз Ніжин», а «під впливом загальної політичної атмосфери, 
ISSN 2308-1902 Актуальні проблеми української літератури і фольклору. 2017. № 25.

щодалі більшого невдоволення кріпосницьким ладом, до Ніжинської «гімназії вищих наук» стали проникати настрої політичного вільнодумства, що невдовзі вилилися в «справу про вільнодумство», до якої була залучена значна частина професорів та учнів» [20, 23], то І. Віноградов детермінує звернення Гоголя до релігійності вкрай опосередкованими його стосунками 3 грецькими (!) православними подвижниками: «Від К.М. Базилі Гоголю міг, зокрема, бути відомим подвиг Константинопольського патріарха Григорія V (причисленого згодом до лику святих), який підтримував визвольний рух греків і постраждав від турків-мусульман у 1821 році (пам'ять священномученика Григорія, патріарха Константинопольського, здійснюється двічі - 10 квітня та 19 червня за ст. ст.). Батько Базилі, Михайло Васильович Базилі, був доволі близьким патріархові - він був старостою патріаршої церкви; і сам малий Базилі був свідком страти патріарха Григорія» $[1,108]$.

Дивовижно, але те, що розкритикував (але ж помітив!) Сєнковський ще в середині позаминулого століття («у этого поэта, подумал верблюд, есть своя риторика нового роду: самые ясные эпитеты у него - бог его знает и чорт его знает; а когда уж хочет он определить предмет $c$ необыкновенною точностью, то употребляет какой-то. Мастер на слог, нечего сказать! Тонко, ясно и вежливо» $[13,239])$, стає в межах як старої, вульгарносоціологічної, так і нової, православної, парадигм непотрібним, малоістотним, дріб'язковим. Наскільки дослідження поетики гоголівської творчості як цілісного феномену стало продуктивним після згаданого звороту до слова в працях Ейхенбаума, Якобсона, В. Віноградова, Тинянова та ін. (до цього питання у зв'язку з проблемою аналізу «Літургії» повернемося в подальших студіях) і наскільки далеко нині відійшов від їхніх здобутків новітній православний детермінізм у гоголезнавстві.

\section{ЛІТЕРАТУРА}

1. Виноградов И. А. Гоголь - художник и мыслитель: Христианские основы миросозерцания. Москва : Наследие, 2000. 448 с. 
2. Виноградов И. А. К истории создания и публикации духовной прозы Гоголя. Гоголь Н.В. Полное собрание сочинений и писем: В 17 m. T. 6: Выбранные места из переписки с друзьями / Сост., подгот. текстов и коммент. И.А. Виноградова, В.А. Воропаева. Москва : Издательство Московской Патриархии, 2009. С. 419-542.

3. Boponaев B. A. «Размышления о Божественной Литургии» Николая Гоголя: из истории создания и публикации. Вестник Православного Свято-Тихоновского гуманитарного университета. Серия 2: История. История Русской Православной Церкви. 2003. № 1. C. 10-30.

4. Гоголь Н. В. Полное собрание сочинений и писем: В 17 т. / Сост., подгот. текстов и коммент. И. А. Виноградова, В. А. Воропаева. Москва : Издательство Московской Патриархии, 2009.

5. Михед П. Апостольський проект Миколи Гоголя (спроба реконструкції). Михед П. Слово художнє, слово сакральне... Збірник статей. Ніжин : ТОВ "Видавництво «АспектПоліграф», 2007. С. 4-24.

6. Барабаш Ю. Гоголезнавство в Україні та поза нею. Барабаш Ю. У напрямку до Гоголя. К. : Темпора. 2015. С. 251-262.

7. Иером. Симеон (Томачинский). Гоголь - самый церковный писатель в русской литературе. Интерфакс. Религия. URL: http://www.interfax-religion.ru/?act=interview\&div=215 (дата звернення: 20.11.2017).

8. Диак. Иоанн Нефёдов. «Размышления о Божественной Литургии» Н. В. Гоголя: церковно-практический комментарий к одному из самых читаемых произведений классика. Журнал Московской Патриархии. 2010. № 5. С. 84-88.

9. Якобсон Р. О художественном реализме. Якобсон Р. Paботы по поэтике: Переводыл / Сост. и общ. ред. М. Л. Гаспарова. Москва : Прогресс, 1987. С. 387-393.

10. Виноградов B. В. Натуралистический гротеск: (Сюжет и композиция повести Гоголя «Нос»). Виноградов В. В. Поэтика русской литературы: Избранные трудыл. Москва : Наука, 1976. С. 5-44.

11. Виноградов B. Гоголь и натуральныя школа. Ленинград : Культурнопросветительское трудовое товарищество «Образование», 1925. 76 с.

12. Шевырев С. П. «Похождения Чичикова, или мертвые души», поэма Н. В. Гоголя (Статьи I и II). Lib.ru/Классика. URL: http://az.lib.ru/s/shewyrew_s_p/text_0080.shtml (дата звернення: 20.11.2017).

13. Сенковский О. И. Рукописная редакция статьи о «Мертвых душах»/ Примеч. Н. Мордовченко. Н. В. Гоголь: Материальь и исследования / АН СССР. Ин-т рус. лит.; Под ред. В. В. Гиппиуса; Отв. ред. Ю. Г. Оксман. Москва; Ленинград : Изд-во АН СССР, 1936. T. 1. C. 226-249.

14. Эйхенбаум Б. Как сделана «Шинель» Гоголя. Эйхенбаум Б. О прозе: Сб. cm. I Сост. и подгот. текста И. Ямпольского; Вступ. ст. Г. Бялого. Ленинград : Худож. лит. Ленингр. отд-ние, 1969. С. 306-326.

15. Якобсон P. Про реалізм у мистецтві. ВАПЛІТЕ. Літературно-художній журнал.1927. № 2. С. 163-170.

16. Тынянов Ю. Гоголь и Достоевский (к теории пародии). Тынянов Ю. Поэтика. История литературыл. Кино / Отв. ред. Б. А. Каверин, А. С. Мясников. Москва : Наука, 1977. C. 198-226.

17. Виноградов И. А. Самая патриотическая книга нашей словесности («Выбранные места из переписки с друзьями Николая Гоголя»). Литературный факт. 2017. № 5. С. 416426.

18. Воропаев B. Последние дни жизни Н. В. Гоголя как духовная и научная проблема. Филаретовский альманах. 2009. С. 114-127.

19. Машинский С. И. Предисловие. Н.В. Гоголь в воспоминаниях современников / Ред., предисл. и коммент. С. И. Машинского. Москва : Гос. издат. худож. лит., 1952. С. 5-39. 
20. Машинский С. И. Художественный мир Гоголя: Пособие для учителей. 2-е изд. Москва : Просвещение, 1979. 432 с.

\section{REFERENCES}

1. Vinogradov, I. (2000). Gogol - hudozhnik i myslitel: Hristianskie osnovy mirosozertsaniya [Gogol - artist and thinker: Christian fundamentals of worldview]. Moscow: Nasledie, 448 s. [In Russian]

2. Vinogradov, I. (2009). K istorii sozdaniya i publikatsii duhovnoy prozy Gogolya [Towards creation and publishing Gogol's spiritual prose]. In N. Gogol, Polnoe sobranie sochineniy $i$ pisem [Complete collection of works and letters]. (Vol. 6, pp. 419-542). Moscow: Izdatelstvo Moskovskoy Patriarhii. [In Russian].

3. Voropaev, V. (2003). «Razmyshleniya o Bozhestvennoy Liturgii» Nikolaya Gogolya: iz istorii sozdaniya i publikatsii ["Reflections on the Divine Liturgy" by Nikolay Gogol: of the history of creation and publishing]. Vestnik Pravoslavnogo Svyato-Tihonovskogo gumanitarnogo universiteta. Seriya 2: Istoriya. Istoriya Russkoy Pravoslavnoy Tserkvi, (1), 10-30. [In Russian].

4. Gogol, N. (2009). Polnoe sobranie sochineniy i pisem [Complete collection of works and letters]. Moscow: Izdatelstvo Moskovskoy Patriarhii. [In Russian].

5. Mykhed, P. (2007). Apostolskyi proekt Mykoly Hoholya (sproba rekonstruktsii) [Mykola Hohol's apostle project (an attempt of reconstruction)]. In P. Mykhed, Slovo hudozhnie, slovo sakralne... Zbirnyk statey [Word of art word of sacrum... Collection of articles]. (pp. 4-24). Nizhyn: TOV «Vydavnytstvo «Aspekt-Polihraf». [In Ukrainian].

6. Barabash, Yu. (2015). Hoholeznavstvo v Ukrayini ta poza neyu [Hohol studies in Ukraine and beyond]. In Yu. Barabash, U napryamku do Hoholya [In direction to Hohol] (pp. 251262). Kyiv: Tempora. [In Ukrainian].

7. Ierom. Simeon (Tomachinskiy) (2017). Gogol - samyiy tserkovnyiy pisatel v russkoy literature [Gogol - the most ecclesiastic writer in Russian literature]. Retrieved from: http://www.interfax-religion.ru/?act=interview\&div=215. [In Russian].

8. Diak. Ioann Nefyodov (2010). «Razmyshleniya o Bozhestvennoy Liturgii» N. V. Gogolya: tserkovno-prakticheskiy kommentariy k odnomu iz samyih chitaemyih proizvedeniy klassika ["Reflections on Divine Liturgy" by N. V. Gogol: ecclesiastic and practice commentary to one of the most readed creation by the writer]. Zhurnal Moskovskoy Patriarhii, (5), 84-88. [In Russian].

9. Yakobson, R. (1987). O hudozhestvennom realizme [On art realism]. In R. Yakobson, Raboty po poetike: Perevody [Works on poetics: Translations]. (pp. 387-393). Moscow: Progress. [In Russian].

10. Vinogradov, V. (1976). Naturalisticheskiy grotesk: (Syuzhet i kompozitsiya povesti Gogolya «Nos») [Naturalistic grotesque: Plot and composition of Gogol's story “The Nose"]. In V. Vinogradov, Poetika russkoy literaturyi: Izbrannyie trudy [Poetics of Russian literature: Selected works] (pp. 5-44). Moscow: Nauka. [In Russian].

11. Vinogradov, V. (1925). Gogol i naturalnyiya shkola [Gogol and natural school]. Leningrad: Kulturno-prosvetitelskoe trudovoe tovarischestvo "Obrazovanie”. [In Russian].

12. Shevyirev, S. (2017). «Pohozhdeniya Chichikova, ili mertvyie dushi», poema N.V. Gogolya. ["Adventures of Chichikov, or The dead souls", poem by N. V. Gogol]. Retrieved from: http://az.lib.ru/s/shewyrew_s_p/text_0080.shtml. [In Russian].

13. Senkovskiy, O. (1936). Rukopisnaya redaktsiya stati o «Mertvyih dushah» [Written version of article about "Dead souls". In V. Gippius (Ed.), N. V. Gogol: Materialyi i issledovaniya [N. V. Gogol: Sources and studies] (Vol. 1, pp. 226-249). Moscow; Leningrad: Izd-vo AN SSSR. [In Russian]. 
14. Eyhenbaum, B. (1969). Kak sdelana «Shinel» Gogolya [How Gogol's "Overcoat" is made]. In B. Eyhenbaum, O proze [On prose] (pp. 306-326). Leningrad: Hudozh. lit. Leningr. otdnie. [In Russian].

15. Yakobson, R. (1927). Pro realizm u mystetsti [On realism in art]. VAPLITE. Literaturnokhudozhnii zhurnal, (2), 163-170. [In Ukrainian].

16. Tynyanov, Yu. (1977). Gogol i Dostoevskiy (k teorii parodii) [Gogol and Dostoevskiy (towards the theory of parody]. In Yu. Tyinyanov, Poetika. Istoriya literaturyi. Kino [Poetics. History of literature. Cinema]. (pp. 198-226). Moscow: Nauka. [In Russian].

17. Vinogradov, I. (2017). Samaya patrioticheskaya kniga nashey slovesnosti («Vyibrannyie mesta iz perepiski s druzyami Nikolaya Gogolya» [The most patriotic book of our art ("Selected places of Nikolay Gogol's correspondence with friends]. Literaturnyiy fakt. (5), 416-426. [In Russian].

18. Voropaev, V. (2009). Poslednie dni zhizni N. V. Gogolya kak duhovnaya i nauchnaya problema [N. V. Gogol's last days as spiritual and scientific problem]. Filaretovskiy almanah, 114127. [In Russian].

19. Mashinskiy, S. (1952). Predislovie [Preface]. In S. Mashinskiy, (Ed.). N. V. Gogol v vospominaniyah sovremennikov [N. V. Gogol in memoirs of contemporaries]. (pp. 5-39). Moscow: Gos. izdat. hudozh. lit. [In Russian].

20. Mashinskiy, S. (1979). Hudozhestvennyiy mir Gogolya: Posobie dlya uchiteley [Art world of Gogol: Teacher's handbook]. ( $2^{\text {nd }}$ ed.). Moscow: Prosveschenie. [In Russian].

\title{
Аннотация \\ Мыхайло Жилин. «Размышления о Божественной Литургии» Николая Гоголя: между поэтикой и экзегетикой.
}

Статья посвящена сопоставлению двух традиций изучения творчества Гоголя формалистической и православно-экзегетической. Первая традиция в общетеоретическом плане была продолжена формалистическим направлением в литературоведении. В то же время современная русская наука о Гоголе рассматривает его позднее творчество, исходя исключительно из представления о его религиозном характере, редуцируя художественность. В результате методология становится жертвой нового, на этот раз религиозного, детерминизма, сходного по своей природе со старой советской методологической традицией - вульгарным социологизмом.

Ключевые слова: Николай Гоголь, «Размышления о Божественной Литургии», поэтика, детерминизм, формализм, Православие.

\begin{abstract}
Mykhailo Zhylin. Introduction to the analysis of "Reflections on the Divine Liturgy" by Nikolai Gogol: between poetics and exegesis.

The article is devoted to the comparison of two traditions of the study of Gogol's creativity - a formalistic one, originating from the well-known article of Eichenbaum, and Orthodox-exegetical one, prevailing (especially in relation to the late work of the writer) in modern Russian science. The main conclusions within the first discourse belong to Roman Jakobson, who defined the key parameters of the «transformed realism» of Gogol and other classics, hiding in the seemingly secondary elements of the work. This tradition was continued in general theoretical terms by a formalistic direction in literary criticism.

At the same time, modern Russian science about Gogol examines his later work («Selected Places from Correspondence with Friends», «Reflections on the Divine Liturgy») based solely on the idea of his religious nature, reducing artistry. As a result, firstly, there is a disengagement from the old Gogol tradition, and secondly, all of Gogol's work is torn into two parts that are inert towards each other; in the third, and most importantly, the methodology becomes a victim of a new
\end{abstract}


ISSN 2308-1902 Актуальні проблеми української літератури і фольклору. 2017. № 25.

one, this one once religious, determinism. The latter distorts our understanding of artistic creativity as such, replacing the need for its study by exposing an external context in relation to it. In general, this new determinism repeats the Soviet methodological tradition, called vulgar sociology.

Key words: Nikolay Gogol, «Reflections on the Divine Liturgy», poetics, determinism, formalism, Orthodoxy.

Стаття надійшла до редакційної колегії 4.12.2017 року 